\title{
Authorship of scientific articles within an ethical-legal framework: quantitative model
}

\author{
Martha Y. Vallejo ${ }^{1}$, Alberto Acosta ${ }^{2}$, Gustavo Palacio Correa ${ }^{3}$
}

Received: 9-09-12 Accepted: 23-11-2012 Published on line: 4-12-2012

Edited by Alberto Acosta

\begin{abstract}
Determining authorship and the order of authorship in scientific papers, in modern interdisciplinary and interinstitutional science, has become complex at a legal and ethical level. Failure to define authorship before or during the research, creates subsequent problems for those considered authors of a publication or lead authors of a work, particularly so, once the project or manuscript is completed. This article proposes a quantitative and qualitative model to determine authorship within a scientific, ethical and legal frame. The principles used for the construction of this design are based on 2 criteria: a) stages of research and scientific method involving: 1. Planning and development of the research project, 2. Design and data collection, 3. Presentation of results, 4. Interpretation of results, 5. Manuscript preparation to disseminate new knowledge to the scientific community, 6 . Administration and management, and b) weighting coefficients in each phase, to decide on authorship and ownership of the work. The model also considers and distinguishes whether the level and activity performed during the creation of the work and the diffusion of knowledge is an intellectual or practical contribution; this distinction both contrasts and complements the elements protected by copyright laws. The format can be applied a priori and a posteriori to the completion of a project or manuscript and can conform to any research and publication type. The use of this format will quantitatively resolve: 1 . The order of authorship (first author and co-author order), 2. Determine the inclusion and exclusion of contributors, taking into account ethical and legal principles, and 3. Percentages of economic rights for each authors.
\end{abstract}

Keywords: Scientific article, author, coauthor, weighting coefficient, collaborative, ethical, legal, research, order of authorship, publication, legal right holder, ownership.

1 BIO\&OIL s.a.s., Calle100 60-04 Ofc. 211 C.C. Master Center. Bogotá, Colombia.

2 Unidad de Ecología y Sistemática, Departamento de Biología, Facultad de Ciencias, Pontificia Universidad Javeriana, Bogotá, D.C., Colombia.

3 Palacio \& Ballesteros. Carrera 14 No. 94A - 10, Oficina 402. Edificio Condominio Chicó 94ª Bogotá D.C. - Colombia. www. palacioballesteros.com.
Autoría en artículos científicos dentro de un marco ético legal: modelo cuantitativo. Resumen. En la ciencia moderna, interdisciplinaria e interinstitucional, definir quién es autor y el orden de autoría en artículos científicos se ha convertido en problema a nivel ético y legal. No aclarar la autoría antes o durante la realización de la investigación genera problemas entre los que se consideran autores. Este artículo propone un formato cuantitativo y cualitativo para determinar autorías dentro del marco científico, ético y legal. Los principios utilizados para la construcción de este formato se fundamentaron en 2 criterios: a) fases de investigación y método científico; involucrando: 1. planificación y elaboración del proyecto de investigación, 2. diseño y obtención de datos, 3. presentación de resultados, 4. interpretación de resultados, 5. preparación del manuscrito para la difusión del nuevo conocimiento, y 6. administración y gestión; y b) coeficientes de ponderación en cada fase, para tomar decisiones de autoría y titularidad de obra. De la misma manera el formato considera y diferencia que fase y actividad, realizada dentro de la creación de la obra y difusión del conocimiento, es aporte práctico o intelectual; lo cual contrasta y complementa lo que la ley de derechos de autor protege. El formato es aplicable apriori y a posteriori a la realización de un proyecto o manuscrito y adaptable a cualquier tipo de investigación y publicación, resolviendo cuantitativamente: 1 . Orden de autores (primer autor y orden de coautores), 2. Inclusión y exclusión de colaboradores considerando principios éticos y legales y 3. Porcentajes de derecho patrimonial para cada autor.

Resumo. Na ciência moderna, interdisciplinar e inter-institucional, a definição do que é um autor e da ordem de autoría em trabalhos científicos tornou-se um problema de ética e legal. A carência de definir autoría, antes ou durante a realização de pesquisas, gera problemas entre os autores considerados. Este artigo propõe um formato quantitativo e qualitativo para determinar a autoría dentro de uma estrutura científica, ética e legal. Os princípios utilizados na construção deste formato basearam-se em dois critérios: a) as fases do método de pesquisa científica, envolvendo: 1. planejamento e escrito da pesquisa, 2. delineamento e coleta de dados, 3. apresentação dos resultados, 4. interpretação dos resultados, 5. preparação do manuscrito para a divulgação de novos conhecimentos, e 6 . administração e gestão, e, b) as fases ponderadas, para tomar decisões de autoría e de propriedade da obra. $O$ formato considera e inclui a diferença entre fase e atividade, realizadas dentro da criação da obra e disseminação do conhecimento, a contribuição intelectual ou prática, que contrasta e complementa o que a lei protege em direitos de autor. $\mathrm{O}$ formato se aplica apriori e a posteriori à conclusão de um projeto ou manuscrito e é adaptável a qualquer tipo de pesquisa e publicação, resolvendo quantitativamente: 1. a ordem de autores (primeiro autor e co-autores), 2. inclusão e exclusão de contribuintes, considerando os princípios éticos e legais, e 3. os percentuais de direitos econômicos para cada autor. 


\section{Introduction}

The pressure on institutional researchers to publish to maintain their status or economic advantages has increased in recent decades. This, coupled with the globalization of knowledge and the implementation of bibliometric indices such as the $h$-index, has generated a strategy change in researchers and research groups, encouraging networking (national or international) where authorship is practically conferred to researchers, undeservedly in some cases, in order to inflate or increase the individual's or group's academic production $(1,2)$. Equally, the gratuitous number of authors adjudicated to a single article, not only reduces the value of authorship per capita, but also becomes unethical when funding agencies or prospective employers ascribe knowledge, creativity and expertise in a particular subject to an individual who does not possess them (3). From a legal standpoint, moral and economic rights (ownership) are also attributed to individuals who should not have them (4). We understand moral rights to include (Article 11 of Andean Decision 351 of 1993, art. 30 of Act 23 of 1982): a. Paternity Law (1993 Andean Decision 351 literal b. Article 11): "Claim authorship of the work at any time."; b. Right of integrity (Andean Decision 351 of 1993 letter c. Article 11): "to object to any distortion, mutilation or alteration of the work that is prejudicial to the integrity thereof or to the reputation of the author (...)". c. Disclosure Law (1993 Andean Decision 351 letter a. Article 11): "keep the work unpublished or to disclose it (...)", the author(s) decide(s) whether or not, how, when, and where it is published; d. Law of Amendment (Law 23 of 1982 Article 30) "The author will have the perpetual, inalienable and imprescribtible right to modify his work before or after publication (...)". e. Right of withdrawal (Law 23 of 1982 Section 30 paragraph E). The author has the right to withdraw work from circulation, though accordingly, compensate the damages caused by exercising this right. While economic rights (Andean Decision 351 of 1993 Section 13, 14) establish that the author or, where applicable, their successors, have the exclusive right to carry out, authorize or prohibit any economic exploitation of the work presently or eventually. These include: a. The reproduction of the work by any means or process. b. The communication of the work to the public by any means serving to convey the words, signs, sounds or images. c. The public distribution of copies of the work by means of selling, lending or hiring. The authors of literary and artistic works shall enjoy the exclusive right to authorize the original and copies of their works to be made available to the public through sale or other transfer of ownership: Article 7 of the WCT. d. The importation into the territory of any Member Country of copies made without the authorization of the owner of rights. e. The translation, adaptation, arrangement or other transformation of the work. While the author is alive, moral rights are linked to the natural person(s), author(s) of a work; that connection is so strong and the laws protecting it are so stringent, that they often disallow any legal effects to the contractual arrangements through which this right is diminished or affected in some way. In other words, moral rights are not as readily available to the author, whereas his patrimonial and exploitation rights are (5).

Modern science promotes interdisciplinarity to resolve scientific questions and motivates international collaboration to generate knowledge using networks. This interaction by experts from different disciplines, generates advantages that improve the quality of writing and knowledge and the advancement of science. However, it creates ethical and legal conflicts regarding the inclusion or exclusion, or the order of authorship of articles. It is common for information obtained through networks and published in scientific articles, defined as the first written report, which communicates original research results (6), to have multiple authors (7). The sometimes unwarranted increase in the number of authors per article $(8,9)$ has been a constant in different disciplines, in recent decades. In an original article, authors should claim their contribution and endorse their participation to eliminate any ambiguity regarding each individual's participation $(2,10)$. In theory, each researcher's contribution to the project (original ideas) and manuscript must be such, that eliminating such substantial contribution, would render the work incomplete, senseless or make it impossible to publish (11).

According to Waltz et al., (12) and Katz and Martin (13) one of the issues arising in national, international, and interdisciplinary, interinstitutional collaborations are the disagreements among researchers or entities 
regarding copyright, many of which, arise from miscommunication, cultural or linguistic differences between authors from different countries $(14,7)$, and standards or other intellectual property laws $(15,16)$.

Unjustified authorship in science, can also be due to: a) imposition or pressure, b) inclusion of a prestigious researchers, c) strategy to consolidate research groups, d) institutional obligations (collaboration), and e) lack of understanding of copyright standards (17). In some cases of unjustified authorship, the chief investigator or the researcher with the most experience (thesis director) is listed as first or last author in a publication, regardless of whether this author deserves this merit or it is attributable to another collaborator or student (18), this is called honorary credits $(7,19)$, and from a legal authorship point of view, it is inappropriate. Thereupon, Spiegel and KeithSpiegel (15) have suggested that authorship should only be granted if a substantial contribution to the project or to writing the article was made, this includes the intellectual component that determines the originality of the work $(7,2)$. Despite unjustified authorship being a global matter, the scientific community has yet to reach an agreement to solve authorship issues, by following precise and standardized rules and objectives such as those proposed by some authors $(20,11)$.

The only definition of author under Colombian law, is contained in Article 3 of the Andean Decision 351 of 1993, which states the following: "Author is the natural person who achieves the intellectual creation" of a work. The objective of copyright law is to safeguard human ingenuity and talent, giving authors and titleholders recognition right tools to control their works (literary or artistic). In this legal scenario, a work is defined as any original intellectual creation of artistic, scientific or literary character susceptible of disclosure or reproduction in any form. Although this definition has legal roots, modern doctrine does not refer to the scientific work as an independent or autonomous category from the literary and the artistic work, given that a literary work can have scientific content, but what is relevant for copyright is the way the work is perceived and not the item content (21). In other words, what copyright protects is the literary or artistic expression and not the content of the work or the ideas that are contained in it.

Authorship in ethics is complex, depending on the definition given to who is the "intellectual creator of the work." At first one would assume that authorship would only apply to the individual(s) that express(es) and capture(s) a set of original ideas in a unique way within a work (research project or scientific writing), but when you consider the creation of the work as a whole (e.g., article) this could also include all of those carrying out mechanical tasks or activities (clerks, data collectors, technicians etc.), managing or financing. However, these are all activities that, by themselves, should not automatically attribute authorship (6). This is consistent with statements by Hunt (22), who also indicated that non-creative, mechanical contributions, to transcribe the work, do not attribute authorship to those performing them.

There are different definitions of author (23). According to Huth (22), author is the individual that produces a literary work, who has been attributed a work, and takes public responsibility for its publication. For the American Psychological Association (APA) (24), to be considered an author, an individual must make substantial scientific contributions in research, that is to say, be involved in the statement of the problem, and the formulation of the hypothesis and the experimental design; he or she must assist in the collection of data, conduct statistical analyses, interpret results and write the article (in whole or in part). All these activities require full knowledge of the work, which is not the case in most instances. The International Committee of Medical Journal Editors (ICMJE) (10) has established that an author can be recognized by: a) the conception and design of the work or the analysis and interpretation of data, b) the drafting or the critical revision of the intellectual content of the draft, and c) the approval of the final draft.

At this point it is important to distinguish the concepts of author and owner of economic rights. Based on the information thus far, the author is the natural person or persons that express a set of original ideas (intellectual creation) and complete a considerable number of the activities pertaining to the projectand manuscript necessary to achieve a scientific literary work. The owner of rights, is the person legally empowered to exercise economic exploitation of the work. Generally, the author and the owner of rights are wrapped into the same person; that is, in creating the work, the author will concurrently be the author and the owner of the rights of this work. However, 
one of three things can occur that will dissociate this condition, the author's death, when authorship of the creative work is hired out (e.g., University, NGOs), or when rights are transferred to the State when the work is created within the framework of the duties of a public servant. In the Colombian legal system and that of countries guided by European copyright law, an author can only be a human being, while legal entities such as companies, associations, foundations, etc., may only be owners of rights. As opposed to the Anglo-Saxon system or copyright law where it is possible, under specified conditions, that a legal entity be officially considered as the author of a work (25).

Difficulties in identifying or determining the author, main author (first author), coauthor (a researcher, part of a scientific publication) or collaborator (who may be coauthor because of substantial contributions or included in the acknowledgments on account of a lack of merits) of a literary work can be caused by ethical issues (26), cultural issues, or limited knowledge regarding the publication proccess (27), and misconstruction of legal definitions, intellectual property and copyright. Pertaining to biomedical articles, Rennie et al. (28) suggest researchers initially be called "collaborators" while "authors" are defined. This article will be adopt this suggestion in spite of differences of opinion expressed by authors such as Smith (29).

The literature offers guidelines to define the contribution of each collaborator to a work and determine the author(s), in them, are general principles presented using hierarchical rankings (30), scoring systems (31), spreadsheets (32), simple values for research categories (33), collection of scores for individual contributions in early stages of research (34), quantitative models (35), and scoring criteria (36), values based on impact factor (37), order of authorship using the APGAR (Appearance, Pulse, Gesticulation, Activity and Respiration) scaling method (38) and weighted quantification of the relative contributions of the investigators $(11,39)$. Still, to date, none of the literature has established a consensus of solutions that integrate qualitative and quantitative information and the intellectual and practical contribution of each collaborator to determine authorship and the order of co-authors of a manuscript, or strategies to define who, because of a lack of substantial contribution, must be excluded and therefore have his or her contribution recognized in the acknowledgments $(10,20)$.

According to Erlen et al. (7), Acosta (11), Guallar (39), and the Council of Biology Editors, the sequence of authors of a manuscript can, and should, be defined a priori, by establishing responsibilities, in writing, before the commencement of the project. They point out that each researcher should have the opportunity to be the first author of the publication based on their interest and participation, but if the researcher fails to fulfill his or her commitments, not only can their appearance in co-author order change, but as indicated by Acosta (11) they can be excluded from this order entirely.

Forasmuch, this paper proposes an evaluation format, in the form of a dynamic, flexible spreadsheet, easy to access and implement, and based the activities of each phase of research and execution of a scientific text. Our aim is to help the scientific community resolve the issue of authorship allocation, the order of coauthors and collaborators (to recognize their work in the acknowledgments) and owner rights.

\section{Materials and methods}

The criteria used for the development of this format are based on the scientific method, treated as sequential research process, with stages involving problem definition, formulation of hypotheses, analysis and interpretation of data and results, abstraction and deduction of conclusions regarding the question, following a thoughtful, systematic, controlled and critical procedure to discover new data, facts and solve issues based on a logical analysis of the information $(40,41)$ and the procedures involved in scientific writing. It also provides the actual intellectual and practical contributions of each collaborator.

The proposed spreadsheet, which contains both elements of the scientific method and implicitly, ethical and legal principles (original intellectual contribution), (Supplement A and B, English and Spanish, respectively) is divided into research stages and activities. The activities (e.g., enter data into a statistical program) within the phases (e.g., result analysis) are quantified and the phases are weighted to reach a percentage of relative contribution among collaborators claiming authorship and to determine the order of authorship. The six phases of research presented in this new evaluation format spreadsheet, 
were determined following guidelines by Weltzien et al. (42), Acosta (11) and Guallar (39), these are: 1. Planning; 2. Experimental design; 3. Analysis and presentation of results; 4. Interpretation of results; 5. Manuscript preparation, and 6. Administrative activities. The latter, while not a scientific contribution, is included in authorship and collaborative scoring, because economic resources and in some cases, administrative activities carried out by collaborators, are indispensable to the completion of the work (43, 39). Not all phases and activities presented on the form will apply to every research and type of scientific document being published; the phases and activities may be adjusted (eliminated or included), as required, by the collaborators prior to completing the form.

Following indications by Guallar (39), each phase in this format is evaluated on a $0-100$ percent scale, and each activity is scored on $100 \%$ (unlike Acosta) (11). The use of percentages provides greater flexibility in different scenarios. During the process of evaluation, working in percentages allows activities, phases or even collaborators to be deleted without quantitatively altering the relative contribution as well as making the comparison between them possible.

Once the collaborators disputing authorship have been defined, each one must complete the form. Initially, to assess their contribution to the activities for each phase, where a value of $0 \%$ means no contribution to the activity or, in some cases, an entire phase, and $100 \%$, total participation in an activity or to the phase being evaluated.

Formulas: Following is the mathematical basis used in the Pivot Table to establish the first author, the coauthors (order of authorship) and to determine the collaborators to be included in the acknowledgments (Table 1). These formulas can be viewed or modified by the individual using the material attached to this article (Supplement A and B) (Excel PivotTable, see

Table 1. Formulas to determine first author, authorship order, and collaborators to be included in the acknowledgements, based on relative contributions. For more details see (Supplement A and B).

\section{ACTIVITY CONTRIBUTION TO ONE PHASE}

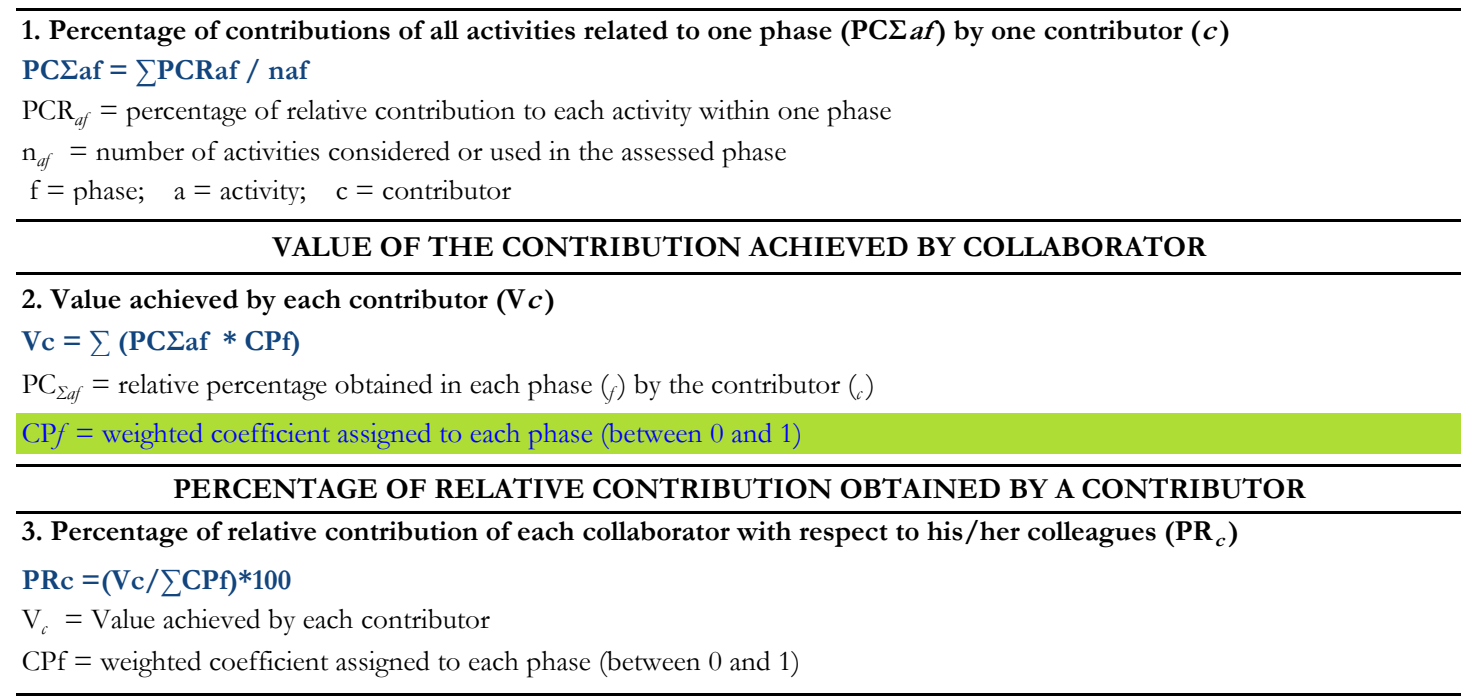

STANDARDIZED PERCENTAGE OF FINAL CONTRIBUTION PER CONTRIBUTOR

4. Percentage of end contribution by each contributor with regards to their colleagues $\left(\mathbf{P R}_{c}\right)$, standardized at $100 \%$

$\mathrm{PFc}=(\mathrm{Vc} * 100) / \sum \mathrm{VC}$

$\mathrm{Vc}=$ Value achieved by each contributor

CUTOFF CRITERION / ACKNOWLEDGEMENTS

5. Cutoff criterion (CL)

$\mathrm{CL}=\mathrm{PFcmax} * 30 / 100$

$\mathrm{PF}_{\text {cmax }}=$ Maximum percentage of contribution achieved by a researcher

Cutoff $30 \%$ with respect to the substantial contribution of the first author; defines co-authorships and acknowledgements 
formula sheet 1 and formula sheet 3 ).

Percentage of contribution of a set of activities to one phase $\left(\mathrm{PC}_{\Sigma a f}\right)$ by a collaborator $\left(_{c}\right)$ is calculated by using the following formula:

$$
\mathbf{P C}_{\Sigma_{\mathrm{af}}}=\sum \mathbf{P C R _ { \mathrm { af } }} / \mathbf{n}_{\mathrm{af}}
$$

where: ${ }_{a}=$ activity; $f_{f}=$ phase; PCR $_{a f}=$ percentage of relative contribution of each activity within a phase; $\mathrm{n}_{a f=}$ number of activities considered or used in the evaluated phase. This formula is used to adjust phase calculations to $100 \%$ as suggested by Guallar (39).

Once the percentage of contribution to each phase is established for each collaborator $\left(\mathrm{PC}_{\Sigma a f}\right)$ the value achieved by each collaborator $\left(\mathrm{V}_{c}\right)$ during research development and production of the manuscript is calculated using the following formula:

$$
\mathbf{V}_{\mathrm{c}}=\sum\left(\mathbf{P C}_{\Sigma \mathrm{af} *} \mathbf{C P}_{\mathrm{f}}\right)
$$

where: $\mathrm{PC}_{\Sigma a f}$ is the relative percentage obtained in each phase $\left({ }_{f}\right)$ by the collaborator $\left({ }_{c}\right) ; \mathrm{CP}_{f}$ is the weighting coefficient assigned to each phase, determined jointly by the collaborators prior to completing evaluation format (Table 1). Weighting coefficients $\left(\mathrm{CP}_{f}\right)$ for each phase of research and publication should range between 0 and 1 . A suggestion to calculate the coefficients is to assign three categories to each activity, depending on the type of contribution made by the collaborator to the work, intellectual, practical or intellectual and practical. Coefficient values of $0.64,0.45,0.36,045$, 1 , and 0.55 , respectively, were arbitrarily established, however, collaborators must agree upon these values a priori. According to Yuksel (44) the probability that a journal will publish a manuscript depends heavily on its originality of ideas, concepts and new contributions to science, for that reason, activities involving intellect should receive a greater weighted value. Moreover, this greater weight to creativity and originality concurs with the legal definition of author.

Later, the score for all the activities per phase are totaled and based on the maximum score of an activity (the one requiring most effort) the realtive value over 1 is calculated for each phase.

To convert this cumulate score value $(\mathrm{V})$ into a percentage, and obtain the percentage of relative contribution for each collaborator in relation to other colleagues $\left(\mathrm{PF}_{c}\right)$, the following formula is applied:

$$
\mathbf{P R}_{\mathrm{c}}=\left(\mathrm{V}_{\mathrm{c}} / \sum \mathbf{C P}_{\mathrm{f}}\right) * 100
$$

To calculate the final standardized percentage of contribution of each collaborator (PF) in relation to other colleagues $(\mathrm{PR})$ the following formula is used:

$$
\mathbf{P F}_{\mathrm{c}}=\left(\mathbf{V}_{\mathrm{c}} * 100\right) / \sum \mathbf{V}_{\mathrm{c}}
$$

where: $\mathrm{V}_{c}=$ Value of contribution achieved by each collaborator.

In this way, the researcher who achieves the highest percentage of PR and PF will be the main contributor to the work as an author and therefore the first author. Those with lower scores will be in order: second, third, fourth, and so on, co-author on the publication.

Now, to establish the minimum cut-off percentage or limit criterion (CL; Table 1) to be excluded from co-authorship due to lack of merits, we have subjectively determined, that a total percentage of contribution by a collaborator (PFC) equal to or less than $30 \%$ of the percentage achieved by the first author (PFcmax) will be considered an non substantial contribution; as a result, this collaborator should be included in the acknowledgments section, thus losing all legal rights to claim authorship or ownership of the work. However, the cut-off percentage (or minimum contribution) should be established by mutual agreement among the collaborators and fixed in the Pivot Table before completing the form (see Supplement A and B).

To calculate the cut-off criterion (CL), the following formula should be used:

$$
\mathrm{CL}=\mathrm{PF}_{\mathrm{cmax}} * 30 / 100
$$

where: $\mathrm{PF}_{\text {cmax }}=$ Maximum contribution percentage achieved by a researcher. A subjective cut-off criterion of $30 \%$, that defines authorship or the collaborator's inclusion in the acknowledgements of the work (not considered an author). Before completing the "Values for Each Activity Within Research Phases" Excel worksheet, researchers must consensually 
determine the rules that will be followed to define authorship (Supplement A or B, assignment of values on spreadsheet 1). These rules cannot be modified once and accord is reached.

\section{Three general steps:}

1. Establish and authorship evaluation format; phases, coefficients, cut-off limit criterion and number of collaborators (Excel PivotTable, spreadsheet 1, Suppl. A and B).

2. Once this is established, participants must complete the values format for each activity in the different research phases (Excel PivotTable, spreadsheet 1, Suppl. A and B), based on the characteristics of each activity (Excel PivotTable, spreadsheet 2, Suppl. A and B).

3. Results will automatically appear in the authorship evaluation form (Excel PivotTable spreadsheet 1, Suppl. A and B); where the conditions were initially established.
Accepted rules to complete authorship evaluation form: Collaborators must, 1. Determine applicable research phases $(f)$ per case. Similarly, hide or insert the number of activity columns $\left({ }_{a}\right)$ necessary (Table 2) and applicable to the type of research and scientific text being published (e.g., original article, note, technical report, reviews or case study). For example, if your research does not include experimental design, the corresponding column should be hidden and any evaluation of activities within this phase should be omitted.

Bailey (2) consensually decide on the weighting coefficients $\left(\mathrm{CP}_{f}\right.$ - between 0 and 1; Table 2, underlined in green; the changes must be made in the Excel Pivot Table, spreadsheet 1) to be applied to each research phase or, the coefficients suggested here may be used. Some phases and activities, because of their intellectual contribution, or input of new original ideas to the manuscript have a greater coefficient in relation to others that are more technical, mechanical repetitive or administrative.

Table 2. Research phases (1, 2, 3, 4, 5,6), with their respective weighting coefficients (in green) and the number of collaborators claiming authorship of the work (A, B, C, D).

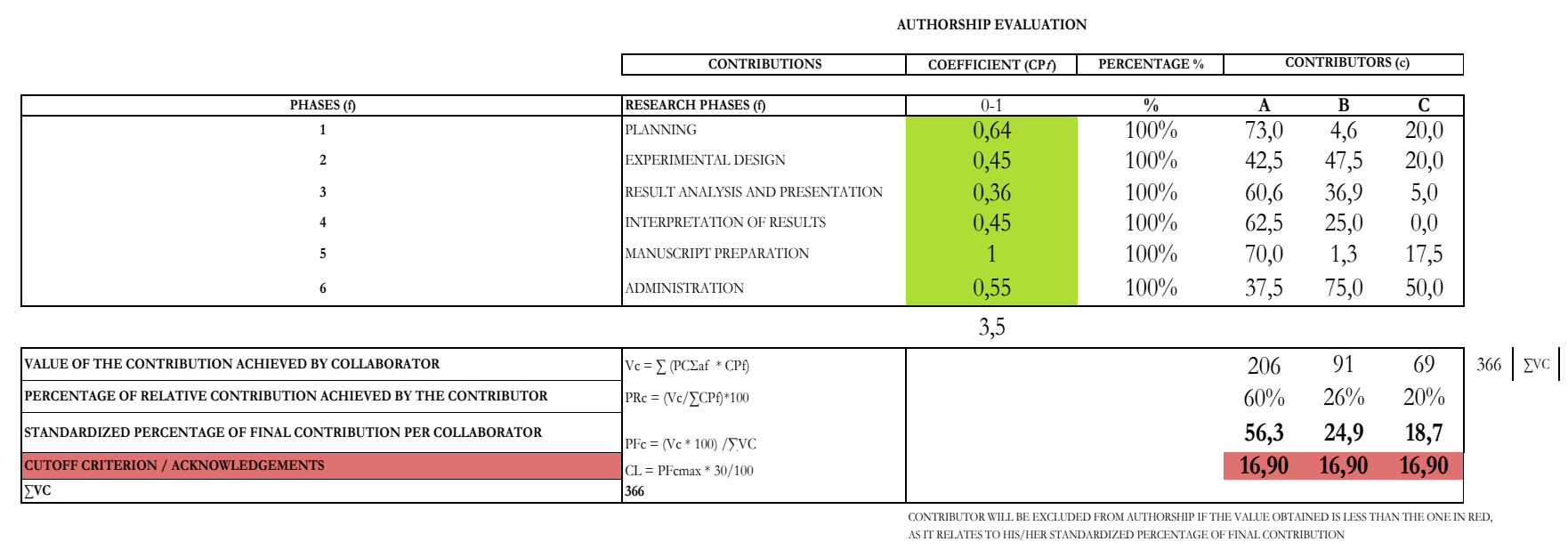

Malone (3) determine the collaborators (A, B, $C, D, E)$ asserting authorship of the work, insert columns according to the number of collaborators (Excel PivotTable, spreadsheet 1).

Márquez-Fernández (4) define cut-off limit criterion (CL, Excel Pivot Table, spreadsheet 1, underlined in red) or minimum percentage a contributor must score to be considered an author or otherwise, excluded from the publication (acknowledgements). This critical value considers the substantial contribution to the work by any collaborator in relation to the author scoring the highest percentage (first author).

How to complete the values format for each activity within the reserach phases: Each contributor will be assigned a column (Table 3). Assign contribution values per collaborator (between 0 and $100 \%$ ) only for those activities in which he or she was involved or those applicable (more information in Suppl. A and B, spreadsheet 1). 
Table 3. Assignment of percentages to the contributions made by each collaborator to each activity (e.g., a, b, c, d, e) of each stage of the research/publication $(1,2,3,4)$. Before completing the form, the collaborators must consensually establish the rules to be followed, and associate each numeral with the characteristics of each one of the research phases.

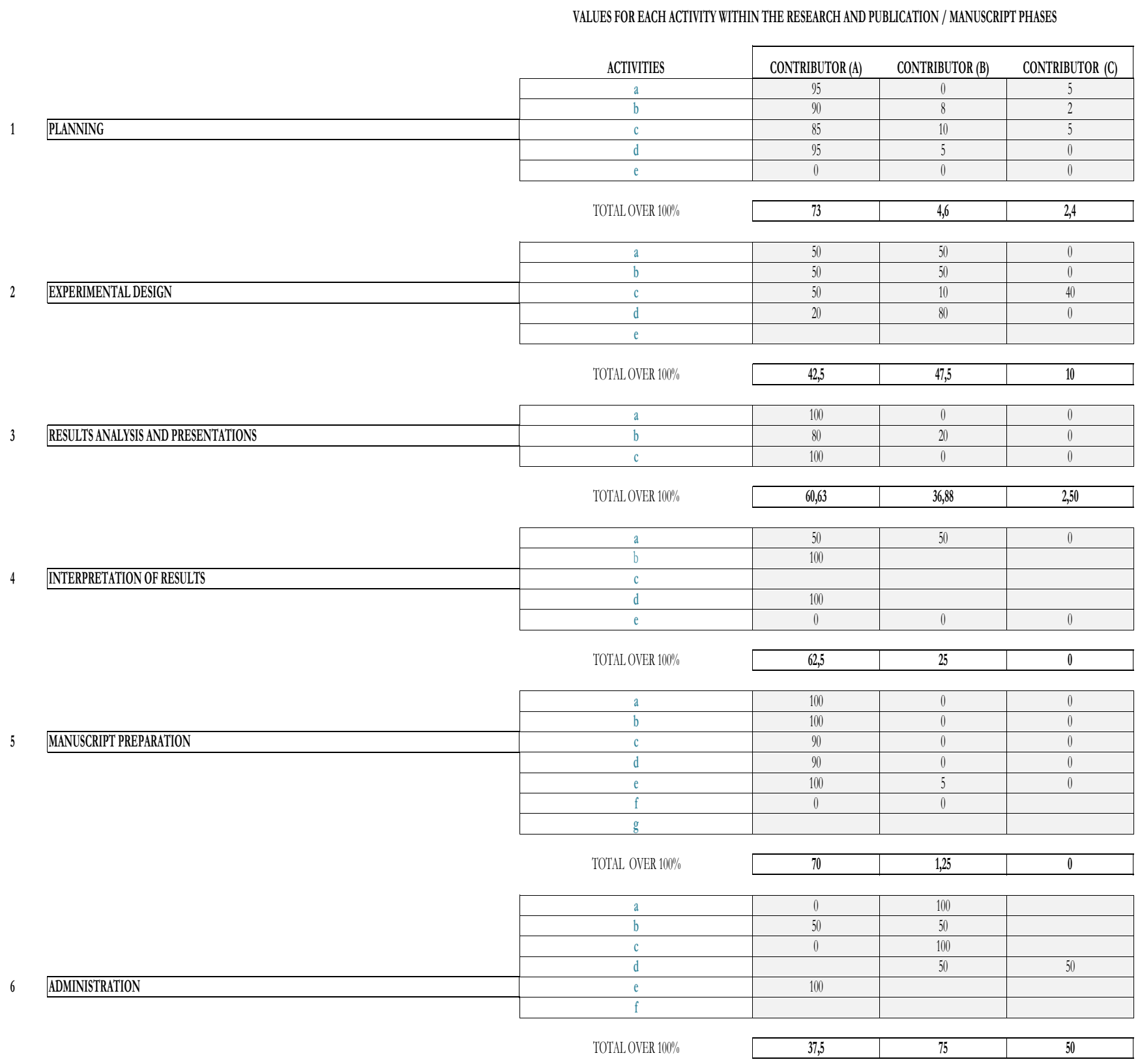

To assign contribution scores (Table 3) and perfom self-evaluations, participants must go to every link (a, b, c, d, e, f) where the detailed characteristics of each activity will appear (Table 4) (see Supplement A and B, spreadsheet 2).

The relative contribution per collaborator in each activity should not exceed 100\%. Contrasting Acosta (21), the valuation percentages for an activity in this format are not based on the researcher's estimation of his or her percentage of participation in comparison to other collaborators to fullfil $100 \%$ of the activity. That is, the complementary valuation criterion does not apply in relation to the contribution of other collaborators but to the activity itself. 
Table 4. Activities and characteristics (a, b, c, d, e) of each one of the phases $(1,2,3,4,5,6)$ of research; previously defined according to the type of investigation and publication (type of scientific comunication, original article, note, review, case study). More information in Supplement A and B, spreadsheet 2.

\section{PLANNING}

a. Contributed his/her knowledge to a topic within the central idea or to theoretical gap within the research (problem conception, question, objectives, hypotheses) in an original or unedited manner. Intellectual author.

b. Concretized in writing (on paper or electronically) the central idea relevant to the research, issues, problems, objectives and hypotheses; material contributor.

c. Wrote the research project (theoretical frame argumentation, theoretical concept selection, methodology, predicted results, timeframe, budget, etc.).

d. Reviewed, compiled, selected and synthesized the pertinent bibliography to argument the project and justify the importance of resolving the problems. Theoretical review of darabases to reach empirical generalizations.

e.

2. EXPERIMENTAL DESIGN

a. Selected research type and design (theoretical, experimental; study variables, dependent and independent, number of repetitions, sample size), for example from a pre-sampling or theoretical review. Case study.

b. Presented data collection stmategy (field or laboratory methods and techniques).

c. Participated in research data collection (whether totally or partially). Variable data can be raken from the field, laboratory, bibliographic review, survers, other type of sampling, soft method sampling recording, etc.

d. Determined the statistical analysis of the variables to reach results.

e. f. RESULTS ANALYSIS AND PRESENTATION

a. Input data into computer for its analysis.

b. Performed statistical analysis (using software), to associate dependent and independent variables. Qualitative research also requires an information analysis component; sensitizing concepts and categorization (micro analysis).

c. Scrutinized and carried out the final presentation of articke results, in the form of: text, graphs or figures.

d.

4. RESULTS INTERPRETATION

a. Interpreted statistical information (test results vs. hypothesis, objective and problem)

b. Integrated the results to reach a conclusion, which fills a void in the existing

knowledge (theoretic gap). The conclusion is an emergent property that

transcends the results towards the theoretical or applied context; it is the

scientific contribution made to the scientific community.

c. Detemined and gave direction to the content of the manuscript, according to the impact of the results in the theoretical or practical context of the rescarch

(bearing of ideas and concepts that make the manuscript original, or contribution

to fill the theoretical-practical void put forward).

d. Wrote and argued oniginal ideas and concepts based on the results and conclusion.

5. MANUSCRIPT PREPARATION

SUGGESTED SCORE BY COMPONENT

SUBJECTIVELY ASSIGNED WEIGHTED VALUE

INTELLECTUAL PRACTICA INTELIECTUALAND PRACTICAL

1

1

2

$\mathrm{X}$

$\mathrm{X}$

$\mathrm{X}$

$\mathrm{x}$

$\mathrm{x}$

0,45

$\mathrm{X}$

$\mathrm{x}$

$\mathrm{x}$

Drafted manuscript summary

$\mathrm{X}$

b. Detemined anguments and wrote manuscript discussion. Verification process,

theory vs. observed. Comparisons and mechanisms that explain the results.

c. Determined anguments and drafted manuscript introduction.

d. Wrote the first versions of the article (including methodology section and

literature).

e. Reviewed the manuscript, re-wrote, focused and provided new paragraphs or ideas for its submittal into publication (editing, writing, syntax, grammar).

f. Translated the manuscript into a second language.

\section{ADMINISTRATION}

a. Presented the proposal to funders.

b. Obtained interinstitutional agreements for the collection of data (permissions,

consents), or the use of materials, equipment, laboratories or facilities.

c. Secured partial or full funding for the devclopment of the rescarch, to publish

or translate the manuscript.

d. Provided as a counterpart: salary, laboratory, equipment, reagents, fungible

material, specimens, personnel, technicians, bibliography, etc

e. Performed managerial (research permits) and administrative (purchases,

account rendering, accounting) dutis.

f.
1,00

0,45

$\mathrm{x}$

$\mathrm{X}$

$\mathrm{x}$

$\mathrm{x}$

$\mathrm{X}$ 
The total contribution of all the activities to the percentage of each phase will be automatically calculated and displayed in each collaborator/ phase column in Table 2. After totaling the scores for the 6 phases (versus colleagues), the highest percentage obtained will be the first author, that is, the collaborator that most contributed from an intellectual (I) or practical (P) point-of-view to the research, the generation of knowledge and to the development of the written scientific article.

\section{Results}

In this proposed format, the results obtained to determine authorship and authorship order as well as the contributor to be included in the acknowledgments will be reflected automatically in the PivotTable (see Excel PivotTable spreadsheet
1, Suppl. A and B and e.g., Table 5). As a result, the order of authors reflects the level of contribution made by the co-authors to the development of the research and the preparation of the manuscript. In the case study (Table 5), the first author will be collaborator A, followed by collaborator C, being first author and co-author. Any collaborator scoring the same or less than the critical value defined, must accept being excluded as author and request his or her inclusion in the acknowledgements section of the publication. In Table 5, collaborator B (15.2\%) scored below the cut-off limit criterion (in this case $18.18 \%$ ) and therefore will not be an author of the work. Unlike Table 2 where all the contributors exceeded the cut-off limit (in red) and as a result, are all considered authors of the work.

Table 5. Case study. Contribution percentage achieved per collaborator (bold), that is, his or her total contribution to the research/manuscript. The minimum percentage value a collaborator must surpass to be attributed authorship, or to classify as co-author of the work.

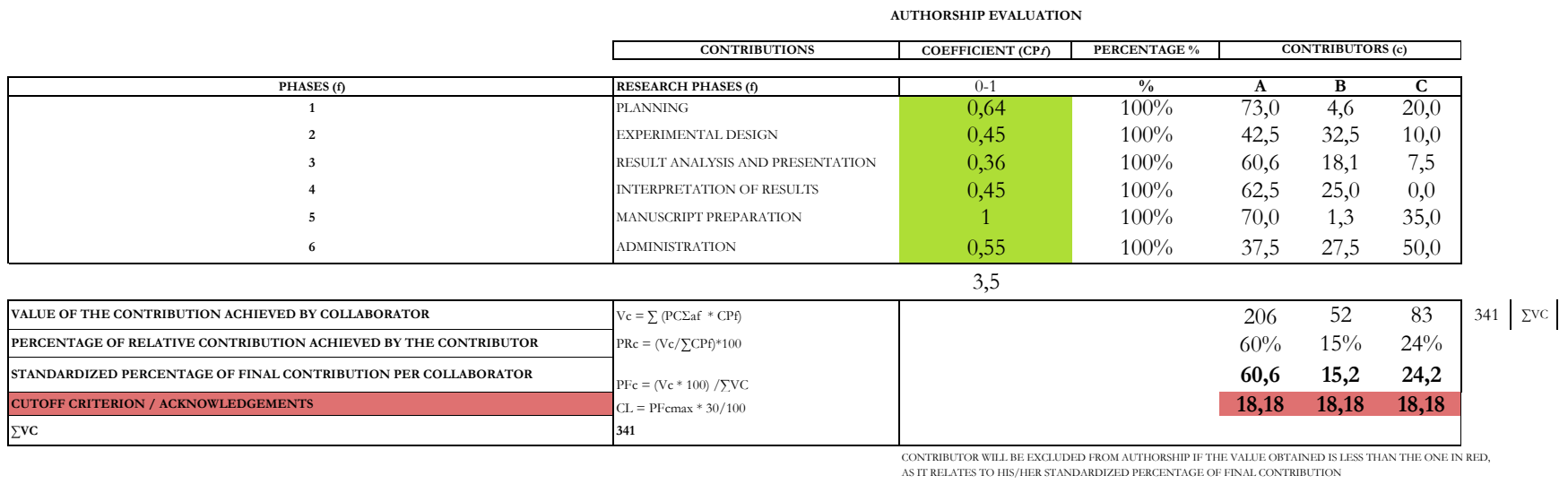

An additional advantage of the proposed calculation procedure is that the relative and substantial contribution of each author can be used to determine the percentage of economic rights of a work, in cases where profit is possible (e.g., patent). Using Table 2 as an example, author A would have the right to $56.3 \%$ of the royalties, B $24.9 \%$ and C $18.7 \%$. This would prevent conflicts between authors and copyright owners. In the case of Table 5, only two authors would be titleholders of the work and entitled to a percentage of royalties proportional to their substantial contribution, assuming the total achieved by them as $100 \%$.

In case of a draw between collaborators, the co-authors can evaluate, discuss and rescore the percentages assigned. Should personal differences and authorship conflicts persist, Erlen et al., $(7,22)$ suggest a mediator group be created formed by individuals outside the project; alternatively, make use of a new "arbitration" resources (check: http://www.ipo.gov.uk/types/copy/c-ownership/ c-jointauthors.htm; http://www.ipo.gov.uk/ ipenforce/ipenforce-dispute.htm; http://www. derechodeautor.gov.co/htm/HOME.htm; Ley 1564 de 2012) to resolve conflicts of authorship.

The format proposed in this article is also a guide to determine the responsibilities of each collaborator, and provide the framework to attain a commitment and fulfillment document regarding potential authorship (Supplement $\mathbf{C}$ and $\mathbf{D}$, Spanish 
and English, respectively). This legal document can be used as supporting evidence to "arbitration" and legal entities. Galindo-Leal (45) state that collaborators should reach written agreements where they assume their responsibilities and define their contributions, before beginning the reserach.

Like this, and having finalized the evaluation process, the first author of the publication must fulfill the following requirements:

1. Possess the maximum percentage of relative participation in relation to colleagues (Table 2 and Table 5).

2. Participate in at least $50 \%$ of total phases defined a priori by the reserachers.

3. Have a thorough knowledge of the research to present it in any scientific event.

4. Spearhead the publication process.

Similarly, the co-authors must achieve:

1. Minimum participation percentage over $30 \%$ in relation to the percentage obtained by the first author.

2. Participation in at least $50 \%$ of all the phases defined a priori by the reserachers.

\section{Discussion}

The quantitative evaluation form to define authorship and order of authorship, based on relative contribution, is presented as a spreadsheet. According to Spiegel and KeithSpiegel (15) a guide or format to define authorship must fulfill the following requirements: 1. It must be flexible, adjustable to estimate authorship credits by type of research and publication; 2 . It must be objective, to establish quantitative differences in authorship and the order of authorship based on the actual relative contribution of each researcher to the literary work, and 3. It must be explicit enough to enable a follow-up or monitoring of the responsibilities and the actual participation of the collaborators, as the evaluation form can be used before, during or after the completion of a project or a manuscript (Suppl.C). Meanwhile Bailey (2) and the International Committee of Medical Journal Editors (ICMJE) (10) state that an individual claiming authorship of a scientific paper must have contributed substantially, and participated in the phases of conception and study design (including the analysis and interpretation of data) and the actual drafting of the article. While other documents (ICMJE) (10) suggest qualitative rather than quantitative criteria, as proposed here, and are based on determining who the intellctual, practical or material author of the work. However, this tends to be subjective giving greater weight to ethical aspects. All of these qualitative and quantitative aspects and attributes have been considered in the proposed format.

Authors like Hanson (46) and others have proposed that the first author should be the individual that has assumed the most responsibility for the research or the article; this format enables this corroboration. Like so, the reader of a scientific article may construe that every coauthor is an author, and as such, possesses an in-depth understanding of the research and is responsible for its content (47), which is no always the case given unjustified authorship.

Although the law makes general provisions, it is the judges who must define specific situations in authorship or credit disputes. Faced with an authorship dispute, a judge will have to fall back on the definition of author, "Author is the individual who achieves the intellectual creation of the work", to determine who should be attributed authorship $(21,25)$. The methodology proposed in this paper becomes an important tool to a judge ruling authorship status by providing an objective criterion, which considers and gives greater weight to the intellectual contribution to the creation of a work. Colombian law does not go into much detail regarding the attribution of credit, or gradations among authors (order of authorship) or between them and other colaborators participating in the creation of a scientific work, as authors or another type of contributors (21). We believe the order of authorship of a publication, though not a legally relevant aspect to a judge, must reflect the authors'conception and participation in the work and his or her degree of knowledge about the subject matter. Consequently, the order of the authors of a publication should be based on each collaborator's amount of substantial contribution and not on subjective aspects that have been traditionally used such as placing the researcher with the longest 
career record or who deserves recognition from the national and international scientific community as the last author. In some European countries, this last author, is the research group or laboratory director, a resource manager or administrator, that due to time constraints is scarcely involved in the phases and activities of research and the writing process but who most likely proposed the original ideas. Under the designed format, these scientists will surely not qualify for authorship, which would generate great controversy; therefore, we suggest that their level of responsibility and participation in the work be higher to merit authorship. The criterion of merit and not the subjectivity should prevail.

It is important to note that legal constructs have outlined some alternatives whereby the misappropriation of ideas and knowledge (unjustified authorship), although not protected by copyright, would generate consequences. For example cases of pre-contractual liability or noncontractual responsibility, or the elements of and objective and subjective sort can be set for cases of unfair competition or even unjust enrichment (undeserved attirbution of ownership of work). In other words, if ideas are not protected by copyright, there are other legal scenarios to validly explore when seeking a solution for the missuse of the ideas of others $(21,25)$.

According to current copyright legislation pertaining to academic environments, because a teacher is hired to advise (provide original ideas), if a work is achieved by a student, he is considered author and owner of all the prerogatives and powers legislation grants, not his or her thesis director $(26,48)$. Likewise, regarding degree and thesis work, Colombian law in considers the person who organized, collected, expressed, gathered and conveyed their ideas in writing, sole and exclusive author of the work, including guidelines and ideas put forward by the director regarding this work (21, 48). However, it is not enough to be the material author of the work as copyright law states, to be considered first or sole author of a manuscript or work, the student should achieve and demonstrate the highest score when completing the form (Suppl. A or B).

Co-authorship in these collaborative works, where there is an intellectual contribution from two or more researchers belonging to the same or different entity $(26,48)$ for example students, technicians, teachers (13), within a project and manuscript should be reviewed in each case. The use of this format may effectively distinguish the contribution of each researcher to the issue and the publication, and ensure that both the moral and economic rights of the collaborators are respected, thus following a more objective and ethical process (49, 25). The ICMJE committee (10) document that indicated the requirements for preparation of a manuscript suggests that individuals having materially contributed to the preparation of the manuscript but not sufficiently to justify the attribution of authorship, should be mentioned after the discussion under a collective heading, such as "researchers" or "participating researchers" or "collaborators".

Some scientists and project directors could benefit from collective works. These works are achieved by a group of authors on the initiative and guidance of a natural person or legal entity that coordinates them that can published under his/her/ its name (see http://www.derechodeautor.gov.co/ htm/HOME.htm). In this case, the law grants the coordinator the ownership of the economic rights (ability to dispose of the economic exploitation of the work) but all participants in the work retain their moral rights (ensure the paternity of the creation and exercise other moral rights) $(25,48)$. In generating this type of work, the format suggested here could also help resolve authorship order and further verify if the director or group coordinator would have the prerogative as first author.

In this scientific environment saturated with productivity indices and indicators, being first author of a publication is becoming increasingly important. It is essential when applying for a job, obtaining points in institutions and rising through the ranks. However, few are aware of what publishing a work entails. From the time the manuscript is submitted to an indexed journal, until it is actually published there are many responsibilities to be assumed. This process involves correcting the document a number of times based on the comments made by the reviewers, or resubmit the manuscript to various magazines (incorporating the suggested changes in each new version), this may take from a few months (2) to a few years (2-4). It also involves raising funds for publication and becoming a spokesman for its 
dissemination.

Authorship is linked to a number of scientific integrity, ethics, justice and accountability issues (46) (50) and therefore must be considered within the scientific community $(51,26)$. The proposed format serves not only to define authorship but also to define the owner of rights of the scientific work (economic rights $=\%$ owned), where the percentage of relative contribution to the work may be equivalent to the ownership and therefore, in the same percentage, to the profits derived by it. This is extremely important if the work is likely to be commercialized or patented.

On the other hand, defining the authors and owners of the work is vital before signing the partial or total transfer to a third party (journal) through copyright (license or contract). It is known that for the author(s) to finally publish and article in a journal (literary creation of a scientific nature), prior acceptance, the copyright must be signed (= author's rights), transferring certain patrimonial rights to the journal through this Agreement (48). This document (copyright transfer) gives the journal the right to reproduce and distribute the article, including reprints (paper), photographic reproductions, microform, translations, electronic reproductions (online, offline) and any other similar type of reproduction, and implicitly, the right to public communication. This document is usually signed by one author who takes responsibility for the other co-authors (Corresponding author), to release the material and transfer rights, while in other journals, it must be signed by each titleholder of the work. Once this is signed, publishers accept no changes in authorship, or authorship order.

Although the number of authors per publication hasincreasedin thelastdecade, due tointerdisciplinary and inter-institutional collaborations, allowing collaboration among scientists to become more important than defining who, by merit, deserves to be the author of the publication is unnacceptable. The commitments established between scientists or research networks, in the attempt to publish studies of a larger spatial, temporal or organismic scale, do not justify meritless authorship. Attributin authorship to anyone that contributes in the projectpublication, despite their minimal contribution (sending samples from one country to another or partial data collection), is unethical and has legal consequences $(21,26,48)$. We hope this proposal will help resolve part of this major issue.

\section{Acknowledgements}

We thank the anonymous reviewers for their valuable comments. The Pontificia Universidad Javeriana (PUJ) for the time provided to complete the publication of this work. We thank Rodolfo J. Ochoa Jimenez (Internal Medicine Specialist, Master of Medical Science, MSc, Researcher, SNI, Regional Hospital-STD Clinic in Colima, Mexico) for his comments and suggestions regarding the Excel PivotTable, as well as graduate and undergraduate students attending the "Scientific Communication and How to Write and Publish" courses at the PUJ. Thanks to Gypsy Español for the translation into English (Traducciones Técnicas $\mathrm{T}$ y $\mathrm{T}$; www. traduccionestyt.com).

\section{Conflict of interest}

This article does not create a conflict of interest. The information contained in the manuscript has either been quoted or we have obtained permission from the authors to disclose it.

\section{References}

1. Laskin M. The gift of authorship. Journal of Oral and Maxillofacial Surgery 1999; 5: 1163.

2. Bailey BJ. What is an author?. Otolaryngol Head Neck Surg 2001; 124 (1): 2-3.

3. Malone RE. Ethical issues in publication of research. J Emerg Nurs 1998; 24 (3): 281-283.

4. Márquez-Fernández A. La Ética del investigador frente a la producción y difusión del conocimiento científico. Revista Venezolana de Gerencia 2001; 6 (16): 632-650.

5. Dirección Nacional del Derecho de Autor de Colombia; Jurisprudencia. 2010 www. derechodeautor.gov.co/, consultado Diciembre 3 de 2012.

6. Day R. How to write and publish a scientific paper. Orix Press Phoenis USA 1994, p 270.

7. Erlen JA, Siminoff LA, Sereika SM, Sutton LB. Multiple authorship: Issues and recommendations. Journal of Professional Nursing 1997; 13 (4): 262-270.

8. Epstein RJ. Six authors in search of a citation: villains or victims of the Vancouver convention? BMJ 1993; 306 (6880): 765-767.

9. Norris RP. Journal authorship patterns have changed considerably in the last 20 years. Can J Nurs Res 1993; 25 (3): 77.

10. ICMJE. Uniform Requirements for Manuscripts Submitted to Biomedical Journals: Ethical 
Considerations in the Conduct and Reporting of Research: Authorship and Contributorship. 1997, www.rsna.org/publications.rad/pdf/pia.pdf, consulted on December 32012.

11. Acosta A. Cómo definir autoría y orden de autoría en artículos científicos usando criterios cuantitativos. Universitas Scientiarum 2007; 12 (1): 67-81.

12. Waltz CF, Nelson B, Chambers SB. Assigning publication credits. Nurs Outlook 1985; 33 (5): 233238.

13. Katz JS, Martin BR. What is research collaboration?. Research Policy 1997; 26: 118.

14. Nehring WM, Durham JD. Multiple authorship in nursing. Nurse Educ 1986; 11 (1): 15-18.

15. Spiegel D, Keithspiegel P. Assignment of publication credits: ethics and practices of psychologists. American Psychologist 1970; 25: 738-747.

16. Lynch CA. Scholarly communication in the networked environment: reconsidering economics and organizational missions. Serials Review 1994; 20: $23-30$.

17. Oyarzún MG, Moreno RB. Quien es el primer autor de un trabajo científico. Rev Chil Ultrasonog 2009; 13 (1): 16-18.

18. Blancett SS. The ethics of writing and publishing. $J$ Nurs Adm 1991; 21 (5): 31-36.

19. Kempers RD. Ethical issues in biomedical publications. Fertility and Sterility 2002; 77 (5): 883888.

20. Claxton LD. Scientific authorship: Part 2. History recurring issues practices and guidelines. Mutation Research 2005; 589 (1): 31-45.

21. Manrique-Hernández RD, Castrillón-Suarez G. Derechos de autor en la investigación científica: la autoría en los artículos de investigación. CES Medicina. 2005; 19 (2): 91-102.

22. Huth EJ. Guidelines on authorship of medical papers. Ann Intern Med 1986; 104 (2): 269-274.

23. Benninger MS. Why is Defining Authorship So Important? Otolaryngology Head and Neck Surgery 2001; 124 (1): 1-3.

24. APA. American Phychological Association. Publication manual of the American Psychological Association (4th edition). 1994. Washington D.C. p. 326.

25. Osorio-Moreno CA. ¿Es legítima la protección penal de los derechos morales de autor?.Opinión Jurídica 2010; 9 (8): 143-158.

26. Oddi LF, Oddi A. Samuel. Student-faculty joint authorship: Ethical and legal concerns. Journal of professional nursing: Official Journal of the American Association of Colleges of Nursing 2000; 16 (4): 219227.

27. Dixon N. Writing for publication - a guide for new authors. International Journal for Quality in Health Care 2001; 13 (5): 417-421.

28. Rennie D, Yank V, Emanuel L. When authorship fails. A proposal to make contributors accountable.
JAMA 1997; 278 (7): 579-585.

29. Smith RH. Authorship is dying: long live contributorship. BMJ 1997; 315 (7110): 696.

30. Davis PJ, Gregerman RI. Parse analysis: a new method for the evaluation of investigators' bibliographies. N Engl J Med 1969; 281 (18): 989990.

31. Ayiomamitis A. Multiple authorship: a mathematical sanctuary. CMAJ 1987; 137 (12): 1077-1078.

32. Schmidt RH.A worksheet for the authorship of scientific articles. Bull .Soc. Am. 1987; 68:.8-10.

33. Hunt R. Trying an authorship index. Nature 1991; 352: 187.

34. Riesenberg D, Lundberg GD. The order of authorship: who's on first?. JAMA 1990; 264 (14): 1857.

35. Klein CJ, Moser-Veillon PB. Authorship: can you claim a byline?. I Am Diet Assoc 1999; 99 (1): 77 79.

36. Theodore GJ. Authorship: Law and Order Academic Emergency Medicine 1999; 6 (4): 297-301.

37. Tscharntke T, Hochberg ME, Rand TA, Resh $\mathrm{VH}$, Krauss J. Author sequence and credit for contributions in multiauthored publications. PLOS Biol 2007; 5 (1): 18.

38. Ahmed SM, Maurana CA, Engle JA, Uddin DE, Glaus KD. A method for assigning authorship in multiauthored publications. Fam Med 1997; 29 (1): 42-44.

39. Guallar S. Un método para cuantificar las contribuciones de los colaboradores en las publicaciones científicas. Animal Biodiversity and Conservation 2007; 30 (1): 71-80.

40. Tamayo y Tamayo M. El proceso de la investigación científica. 4ed. Limusa, México, 2004, p. 440.

41. McMillan JH, Schumacher S. Investigación educativa: Una Introducción conceptual. 5ta ed., Pearson Educación, Madrid España 2007, pp. 656.

42. Weltzien JF, Belote RT, Williams LT, Keller, JF, Engel EC. Authorship in ecology: Attribution, accountability, and responsibility. Front Ecol Environm 2006; 4: 435-441.

43. Altmann S. On authorship and intellectual property. Anim. Behav. Soc. Newsletter 1995; 41 (1): 4-7.

Yuksel A. Writing publishable papers. Tourism Management 2003; 43.(4): 437-446.

44. Galindo-Leal C. Explicit authorship. Bull Ecol Soc Am 1996; 77 (4): 219-220.

45. Hanson SM. Collaborative research and authorship credit: beginning guidelines. Nurs Res 1988; 37 (1): 49-52.

46. Stevens KR. Authorship: yours mine or ours?. Image J Nurs Sch 1986; 18 (4): 151-154.

47. Antequera PR. El Derecho de Autor en el Ámbito Universitario. Comentarios de Jurisprudencia Propiedad Intelectual 2010; 13: 124-149.

48. Denham SA. Stemming the tide of disreputable 
science: implications for nursing. Nurs Forum 1993; 28 (2): 11-18.

49. Sarr MG, Warshaw AL. Responsibility of authorship. Surgery 2002; 2 (3): 521.

50. Fine M, Kurdek LA. Reflections on determining authorship credit and autor-ship order on facultystudent collaborations. American Psychologist 1993; 48: 1141-1147.

\section{Laws from:}

Vega-Jaramillo A. Dirección Nacional de derecho de autor. Unidad Administrativa Especial. Ministerio del Interior y de justicia. 2010. Manual de derecho de autor. Decisión Andina 351 de 1993 art. $3^{\circ}$. Régimen común sobre derecho de autor y derechos conexos.

Vega-Jaramillo A. Dirección Nacional de derecho de autor. Unidad Administrativa Especial. Ministerio del Interior y de justicia. 2010. Manual de derecho de autor. Decisión Andina 351 de 1993 art. 30 de la Ley 23 de 1982.

Vega-Jaramillo A. Dirección Nacional de derecho de autor. Unidad Administrativa Especial. Ministerio del Interior y de justicia. 2010. Manual de derecho de autor. Decisión Andina 351 de 1993 literal b. del artículo 11.
Vega-Jaramillo A. Dirección Nacional de derecho de autor. Unidad Administrativa Especial. Ministerio del Interior y de justicia. 2010. Manual de derecho de autor. Decisión Andina 351 de 1993 literal c. del artículo 11.

Vega-Jaramillo A. Dirección Nacional de derecho de autor. Unidad Administrativa Especial. Ministerio del Interior y de justicia. 2010. Manual de derecho de autor. Literal a. Articulo 11.

Vega-Jaramillo A. Dirección Nacional de derecho de autor. Unidad Administrativa Especial. Ministerio del Interior y de justicia. 2010. Manual de derecho de autor. Tratado de la OMPI. Derecho de Autor artículo 7 del WCT.

Vega-Jaramillo A. Dirección Nacional de derecho de autor. Unidad Administrativa Especial. Ministerio del Interior y de justicia. 2010.

Vega-Jaramillo A. Dirección Nacional de derecho de autor. Unidad Administrativa Especial. Ministerio del Interior y de justicia. 2010. Manual de derecho de autor. Decisión Andina 351

Código Penal colombiano. De las Normas Rectoras de la Ley Penal Colombiana violación a los derechos morales de autor artículo 270-272.

Código General del Proceso. Dirección Nacional de Derecho de Autor. Ley 1564 de 2012. http:// www.derechodeautor.gov.co/htm/HOME.htm 